\section{NHS Health Advisory Service}

The NHS Health Advisory Service will shortly be appointing team members for its 1989-1990 programme of visits to services for elderly people and for mentally ill people.

The Director, Professor Philip Seager, would welcome applications from consultant psychiatrists, who are not already on the Health Advisory Service's panel, to be seconded to teams. Assignments are of three to five weeks' duration but applicants should also state if they would be interested in a continuous three or six months' secondment. Employing Authorities are reimbursed by the Department of Health for the salaries and expenses of those undertaking assignments.

The ad hoc multidisciplinary teams (comprising a consultant psychiatrist or geriatrician, a general manager, and managers of nursing, occupational therapy or physiotherapy, and social services) will be visiting Health Districts throughout England and Wales to help the relevant Authorities to assess and improve their services for the client groups concerned, and in particular to advise on the better management of resources and the ways in which the services might be changed or developed in the future. Teams bring their own experience of similar working situations to bear in a form of peer review; visits have proved themselves helpful educational experiences for team members. The final week of each assignment is spent at the Health Advisory Service's headquarters at Sutton writing the report, which is subsequently submitted to the Secretary of State and becomes a public document.

Applications, accompanied by a curriculum vitae, should be sent as soon as possible to: The Director, NHS Health Advisory Service, Sutherland House, 29-37 Brighton Road, Sutton, Surrey SM2 5AN.

\section{Register of expert witnesses}

The Legal Practice Directorate of the Law Society is currently up-dating its register of expert witnesses who can offer assistance to solicitors in litigation.

Any members who wish to assist should contact the Information Officer, Edwina Dunne, at the Law Society, 12 Chancery Lane, London WC2A 1PL and should enclose the following details:

(1) name

(2) background and experience

(3) services offered

(4) willingness to undertake medico-legal work (including negligence) as appropriate.

\section{Diploma in Psychotherapy (University of Liverpool)}

Applications are invited for the above multidisciplinary course in psychotherapy which starts its ninth annual intake in October 1989. The course is parttime, extending over two years, and leads to the University qualification of Diploma in Psychotherapy. Application forms and further details are available from: The Secretary, Sub Department of Clinical Psychology, New Medical School, Ashton Street, PO Box 147, Liverpool L69 3BX. Completed application forms should be returned by 28 April 1989.

\section{Back issues of the Journal}

Dr John Pippard, Elizabeth House, 9 Princes Avenue, Woodford Green, Essex IG8 0LL, offers runs of back issues of the Journal of Mental Science from 1955-1962 and The British Journal of Psychiatry from 1963-1984. 